\title{
Effect of fire-derived chemicals on germination and seedling growth in Mediterranean plant species
}

\author{
Şükrü Serter Çatava,*, Köksal Küçükakyüz ${ }^{\mathrm{a}}$, Çăgatay Tavşanoğlư ${ }^{\mathrm{b}}$, \\ Juli G. Pausas ${ }^{\mathrm{C}}$ \\ a Department of Biology, Muğla Sitkı Koçman University, Kötekli 48000, Muğla, Turkey \\ ${ }^{\mathrm{b}}$ Fire Ecology and Seed Research Lab., Division of Ecology, Department of Biology, Hacettepe University, Beytepe \\ 06800, Ankara, Turkey \\ ${ }^{\mathrm{c} C e n t r o ~ d e ~ I n v e s t i g a c i o n e s ~ s o b r e ~ D e s e r t i f i c a c i o n, ~ C o n s e j o ~ S u p e r i o r ~ d e ~ I n v e s t i g a c i o n e s ~ C i e n t i ́ f i c a s ~(C I D E-C S I C), ~}$ \\ Ctra. Naquera Km 4.5 (IVIA), Montcada, Valencia 46113, Spain
}

The final version will be published in Basic and Applied Ecology (2018), https://doi.org/10.1016/j.baae.2018.05.005

\begin{abstract}
The promoting effect of smoke-derived chemicals (e.g. karrikinolide and cyanohydrin) on germination in many plants from Mediterranean-type ecosystems such as South Africa and south-western Australia is well documented. However, very little is known about (1) the relative importance of different compounds and their possible interactive effects, (2) their role in enhancing seedling growth in wild plants, and (3) their effect on the germination of plants in the Mediterranean Basin. To fill these gaps in knowledge, we performed experiments to evaluate the effect of smoke water, karrikinolide, mandelonitrile (a cyanohydrin analogue), potassium nitrate and gibberellic acid on the germination and seedling growth of 37 species from the Mediterranean Basin. The results suggest that germination and/or seedling growth of 21 species are enhanced by at least one of the fire-derived chemicals. There were positive correlations between most of the compounds tested in terms of germination response, but synergetic and inhibitory effects were also detected. Stimulation of germination was most prominent in species with annual life cycles. Fire-derived chemicals were more effective in stimulating root growth than shoot growth. In conclusion, we provide novel evidence that the recruitment of different Mediterranean species may be enhanced by different smoke compounds, and that synergetic and inhibitory effects of chemical compounds are important in the germination ecology of plants.
\end{abstract}

Keywords: Fire; Germination; Smoke; Karrikinolide; Cyanohydrin; Annuals

\section{Introduction}

Fire is a common disturbance that affects a large proportion of ecosystems (Bond \& Keeley 2005; Chuvieco, Giglio, \& Justice 2008) and a significant driver of global plant diversity (Pausas \& Ribeiro 2017). Even though

\footnotetext{
${ }^{*}$ Corresponding author.

E-mail address: sertercatav@mu.edu.tr (Ş.S. Çatav).
}

most current fires have an anthropogenic origin, wildfires have affected plant community dynamics since the Paleozoic time (Glasspool, Edwards, \& Axe 2004; Pausas \& Keeley 2009). Therefore, wildfires have been recognized as a natural phenomenon in terrestrial ecosystems (Keeley, Bond, Bradstock, Pausas, \& Rundel 2012), and many plant species have evolved adaptive traits to persist in fire-prone environments. Resprouting from basal lignotubers, serotiny, enhanced flammability, post-fire flowering 
and fire-stimulated seed germination are prominent examples of these adaptive traits (Keeley, Pausas, Rundel, Bond, \& Bradstock 2011; Lamont \& Downes 2011; Pausas, Alessio, Moreira, \& Corcobado 2012). Specifically, fire-stimulated germination results from dormancy-breaking effects of heat or from combustion-related products (e.g. smoke and nitrogenous compounds). Heat can break the physical dormancy of many hard-seeded plants by affecting the permeability of seed coats and disrupting specific structures such as the chalazal plug and lens (Thanos, Georghiou, Kadis, \& Pantazi 1992; Herranz, Ferrandis, \& Martínez-Sánchez 1998; Baskin \& Baskin 2014). On the other hand, even though the capacity to respond to smoke is notably dependent on various factors such as the type and level of seed dormancy, and the timing of germination (Merritt, Turner, Clarke, \& Dixon 2007; Nelson, Flematti, Ghisalberti, Dixon, \& Smith 2012), smoke-stimulated germination has been demonstrated in numerous species from a wide range of phylogenetic and ecological origins (Dixon, Roche, \& Pate 1995; Pierce, Esler, \& Cowling 1995; Keeley \& Bond 1997; Adkins \& Peters 2001; Moreira, Tormo, Estrelles, \& Pausas 2010; Downes, Light, Pos`ta, \& Van Staden 2015; Keeley \& Pausas 2018).

Of the many compounds produced during biomass combustion, the first isolated germination cue was a butenolide (3-methyl-2H-furo[2,3-c]pyran-2-one) named karrikinolide (KAR 1 ) (Flematti, Ghisalberti, Dixon, \& Trengove 2004; Van Staden et al. 2004; Dixon, Merritt, Flematti, \& Ghisalberti 2009). Stimulation of germination in many smoke-responsive species by $\mathrm{KAR}_{1}$ initially suggested that this compound is the main germination stimulant in smoke (Flematti et al. 2007; Chiwocha et al. 2009; Light, Daws, \& Van Staden 2009). However, there is increasing evidence that smokestimulated germination is far more complex (Keeley \& Pausas 2018). The existence of smoke-responsive species that do not respond to $\mathrm{KAR}_{1}$ (Downes, Lamont, Light, \& Van Staden 2010; Flematti et al. 2011) led to the discovery of a new germination cue, the cyanohydrin glyceronitrile (2,3-dihydroxypropanenitrile) (Flematti et al. 2011). Furthermore, the stimulatory effects of cyanohydrin analogues, such as glycolonitrile, acetone cyanohydrin, 2,3,4-trihydroxybutyronitrile and mandelonitrile (hereafter 'MAN'), on germination have also been determined in several studies (Flematti et al. 2011; Baldos, DeFrank, \& Sakamoto 2015; Tavşanoğlu et al. 2017).

In addition to their positive effect on germination, smoke and $\mathrm{KAR}_{1}$ are known to stimulate seedling growth in various plants (Sparg, Kulkarni, Light, \& Van Staden 2005; Van Staden, Sparg, Kulkarni, \& Light 2006; Daws, Davies, Pritchard, Brown, \& Van Staden 2007). This is an ecologically-important factor because growing fast in postfire environments provides a competitive advantage and thus has strong implication for fitness (Brown \& Van Staden 1997; Hanley \& Fenner 1998). However, most studies on this topic have focused on the smoke-induced seedling growth in agriculture (Jain \& Van Staden 2006; Kulkarni, Sparg, Light, \&
Van Staden 2006; Van Staden et al. 2006; Singh, Kulkarni, \& Van Staden 2014), whereas little is known about smoke's impact on wild plants (Moreira et al. 2010).

In comparison with other Mediterranean-type ecosystems (e.g. South Africa and Australia), there is limited knowledge regarding the effect of smoke and smoke compounds on plants in the Mediterranean Basin (reviewed by Moreira \& Pausas 2018). For instance, whereas smokestimulated germination is mainly observed in annual plants (Keeley \& Bond 1997; Keeley \& Fotheringham 1998), most species tested in the Mediterranean Basin are perennials and many are woody. Such studies in the Mediterranean Basin include many species with physically dormant seeds (e.g. Cistaceae, Fabaceae), in which the germination cue is more likely to be heat than smoke. Furthermore, there is lack of information about the effects of specific smoke-derived compounds (KAR 1 and cyanohydrin) on the germination of Mediterranean plant species except Chaenorhinum rubrifolium (Tavşanoğlu et al., 2017). These shortcomings limit our ability to understand the evolutionary aspects of fire in the Mediterranean Basin and correctly frame this region among other Mediterranean-type ecosystems worldwide (Moreira \& Pausas 2018).

Our hypothesis is that smoke, acting through a diversity of compounds, enhances plant fitness (increasing germination or seedling growth) in a range of plants from fire-prone Mediterranean Basin region. Specifically, we aim to test that whether (1) the germination of many Mediterranean plants is sensitive to smoke-derived compounds with a stimulation effect similar to species from other Mediterranean-type ecosystems; (2) this effect is especially common in annual plants; (3) different smoke compounds have different effects on germination, including synergetic effects; (4) germination responses to a smoke compound do not necessarily imply smoke-stimulated germination; and (5) smoke-derived compounds are effective in enhancing the seedling growth of some Mediterranean plants. To achieve these goals, we carried out two experiments to examine the effects of smoke water, specific smoke chemicals and nitrate on the germination and seedling growth of 37 plant species native to the Mediterranean Basin. In addition to these compounds, we also applied gibberellic acid ( $\left.\mathrm{GA}_{3}\right)$, a phytohormone that is considered to have a similar effect to $\mathrm{KAR}_{1}$ (Merritt et al. 2006; Cembrowska-Lech \& Kepczyński 2016).

\section{Materials and methods}

\section{Study area, study species and seed collection}

Fruits of 37 plant species were collected from their natural habitats in fire-prone areas of Muğla Province, southwestern Turkey, eastern Mediterranean Basin (36.8 $8^{\circ}-37.2^{\circ}$ $\mathrm{N}, 22.4^{\circ}-28.2^{\circ} \mathrm{E}$ ). The study area has the typical Mediter- 
Table 1. List of the studied species. GF is growth form (a: annual herb, v: variable herb, p: perennial herb, g: geophyte, w: woody), RA is resprouting ability ('+' = yes, '_' = no, '?' = unknown) and SM is mean seed mass in mg. The species codes given here are used in all tables throughout the paper. The nomenclature follows Davis (1965-1985), and the Angiosperm Phylogeny Website (Stevens 2001 onwards) for family names. Growth form follows Davis (1965-1985) and Paula et al. (2009) while resprouting information was taken from Paula et al. (2009). '*' indicates that the germination experiment was not performed in this species due to insufficient seeds.

\begin{tabular}{|c|c|c|c|c|c|}
\hline Family & Species & Code & GF & RA & SM \\
\hline Apiaceae & Daucus carota L. & DCA & $\mathrm{v}$ & + & 0.77 \\
\hline Apiaceae & Lagoecia cuminoides L.* & LCU & $\mathrm{a}$ & - & 0.62 \\
\hline Apiaceae & Opopanax hispidus (Friv.) Gris. & $\mathrm{OHI}$ & $\mathrm{p}$ & $?$ & 1.38 \\
\hline Apiaceae & Smyrnium rotundifolium Miller & SRO & $\mathrm{v}$ & $?$ & 10.30 \\
\hline Apiaceae & Torilis leptophylla (L.) Reichb. & TLE & $\mathrm{p}$ & $?$ & 2.39 \\
\hline Asparagaceae & Muscari comosum (L.) Miller & MCO & g & + & 4.81 \\
\hline Asparagaceae & Ornithogalum narbonense L. & ONA & g & + & 3.65 \\
\hline Asteraceae & Crepis foetida $\mathrm{L}$ & $\mathrm{CFO}$ & $\mathrm{V}$ & + & 0.34 \\
\hline Asteraceae & Onopordum caricum Hub.-Mor. & OCA & $\mathrm{v}$ & - & 10.14 \\
\hline Asteraceae & Onopordum illyricum L. & OIL & $\mathrm{V}$ & ? & 16.03 \\
\hline Asteraceae & Picris sp. & PSP & $\mathrm{V}$ & ? & 1.38 \\
\hline Asteraceae & Sonchus asper (L.) HILL* & SAS & $\mathrm{v}$ & - & 0.24 \\
\hline Asteraceae & Taraxacum sp. & TSP & $\mathrm{p}$ & ? & 0.36 \\
\hline Asteraceae & Tragopogon longirostis Bisch. Ex Schultz Bip.* & TLO & $\mathrm{v}$ & $?$ & 0.64 \\
\hline Boraginaceae & Paracaryum aucheri (A. Dc.) Boiss. & PAU & $\mathrm{p}$ & ? & 7.24 \\
\hline Brassicaceae & Alyssum fulvescens Sibth. Et Sm. var. fulvescens Sibth. Et Sm. & AFU & $\mathrm{a}$ & - & 0.72 \\
\hline Brassicaceae & Capsella bursa-pastoris (L.) Medik. & $\mathrm{CBU}$ & $\mathrm{a}$ & - & 0.12 \\
\hline Brassicaceae & Isatis tinctoria $\mathrm{L}$. & ITI & $\mathrm{p}$ & ? & 2.32 \\
\hline Caryophyllaceae & Silene behen L. & SBE & a & - & 1.06 \\
\hline Caryophyllaceae & Silene vulgaris (Moench) Garcke var. vulgaris (Moench) Garcke & SVU & $\mathrm{p}$ & - & 1.65 \\
\hline Cistaceae & Cistus creticus L. & CCR & $\mathrm{w}$ & - & 0.71 \\
\hline Cistaceae & Cistus laurifolius L. & CLA & $\mathrm{w}$ & - & 0.90 \\
\hline Cistaceae & Cistus parviflorus Lam. & $\mathrm{CPA}$ & $\mathrm{w}$ & - & 0.70 \\
\hline Cistaceae & Cistus salviifolius L. & CSA & $\mathrm{w}$ & - & 1.54 \\
\hline Cistaceae & Helianthemum salicifolium (L.) Miller & HSA & $\mathrm{a}$ & - & 0.16 \\
\hline Hypericaceae & Hypericum perforatum L. & HPE & $\mathrm{p}$ & + & 0.10 \\
\hline Lamiaceae & Lavandula stoechas L.* & LST & $\mathrm{W}$ & - & 0.73 \\
\hline Lamiaceae & Phlomis bourgaei Boiss. & PBO & $\mathrm{w}$ & + & 5.51 \\
\hline Lamiaceae & Salvia fruticosa Miller & SFR & $\mathrm{w}$ & + & 8.11 \\
\hline Lamiaceae & Stachys cretica L. subsp. smyrnaea Rech. Fil. & SCR & $\mathrm{p}$ & - & 2.91 \\
\hline Lamiaceae & Thymbra spicata L. & TSPI & $\mathrm{w}$ & $?$ & 0.77 \\
\hline Malvaceae & Alcea pallida Waldst. Et Kit. & APA & $\mathrm{p}$ & $?$ & 6.35 \\
\hline Papaveraceae & Papaver rhoeas L. & PRH & a & - & 0.08 \\
\hline Draroa & Avena harhata Pott Ex Link subsn. barhata Pott Ex Link & ABA & a & - & 11.80 \\
\hline Poaceae & Phleum exaratum Hochst. Ex Griseb. subsp. exaratum Hochst. Ex Griseb. & PEX & a & & 0.24 \\
\hline Polygonaceae & Rumex tuberosus L. & RTU & $\mathrm{p}$ & ? & 1.80 \\
\hline Rosaceae & Sanguisorba minor Scop. subsp. minor Scop. & SMI & $\mathrm{p}$ & + & 16.32 \\
\hline
\end{tabular}

ranean climate with a hot, dry summer and a mild, rainy winter. Collections were conducted between May and August 2015, coinciding with the seed dispersal period of each species. For two of the species collected, we were unable to identify the species name and thus we refer to them by the genus name (Picris sp. and Taraxacum sp.; Table 1). Plants from which we collected fruits belonged to a range of growth forms, 32 genera and 14 families, and differed in their seed mass and resprouting ability (Table 1). We considered our collection as representative of both obligate and facultative post-fire seeder species of the Mediterranean flora.
Seeds were separated from fruits by hand (except for single-seeded indehiscent fruits, hereafter 'seeds') and stored in paper envelopes under room conditions ( $c a 22{ }^{\circ} \mathrm{C}$ and $\mathrm{ca}$ $50 \% \mathrm{RH}$ ) until the beginning of the experiment in October 2015. For each species, the mean seed mass was determined by weighing five replicates of 20 seeds (Table 1 ).

\section{Preparation of smoke water and chemical solutions}

Both straw- and cellulose-derived smoke water was used for smoke treatments (coded as SW-STR and SW-CEL, 
respectively). They were obtained by burning $80 \mathrm{~g}$ of wheat straw or filter paper (Whatman No. 1), respectively, using a bee smoker; the smoke was then bubbled through $500 \mathrm{~mL}$ of distilled water in a glass bottle for 12 min (Downes, Light, Pošta, Kohout, \& Van Staden 2013). The obtained smoke water was stored at $4{ }^{\circ} \mathrm{C}$ until used. Even though the composition of these two smoke water solutions was slightly different, we expected a high correlation between them in terms of stimulating germination.

All chemical compounds tested in this experiment $\left(\mathrm{KAR}_{1}\right.$, $\mathrm{GA}_{3}$, MAN and $\mathrm{KNO}_{3}$ ) were purchased from Carbosynth, Merck and Sigma-Aldrich. KAR 1 and $\mathrm{GA}_{3}$ were first dissolved in ethanol (95\%) to make primary stock solutions before storage at $20^{\circ} \mathrm{C}$ until needed. The stock solutions of $\mathrm{KNO}_{3}$ and MAN were prepared just before each experiment with distilled water.

\section{The germination experiment}

Seeds of 33 species were used in this experiment. Solutions of smoke water (5\%), $\mathrm{KAR}_{1}(0.1 \mathbf{\mu M}), \mathrm{KNO}_{3}(10 \mathrm{mM})$ and $\mathrm{GA}_{3}(10 \mathbf{M M})$, as well as distilled water (control) were applied to seeds in Eppendorf tubes for $24 \mathrm{~h}$. Seeds were then sown in Petri dishes containing agar $(0.8 \%)$ as a substrate. Because of the slow release of free cyanide from cyanohydrin solutions (Flematti et al. 2011), for the MAN and $\mathrm{KAR}_{1}$ + MAN treatments, seeds were first incubated in distilled water and $\mathrm{KAR}_{1}$ solution (0.1 $\mathbf{\mu M})$, respectively, for $24 \mathrm{~h}$, and then transferred to an agar medium ( $0.8 \%)$ containing $50 \boldsymbol{\mu M}$ of MAN. The concentrations chosen for each treatment were based on previous studies (Flematti et al. 2004, 2011; Downes et al. 2013; Cembrowska-Lech, Koprowski, \& Kępczyński 2015; Çatav, Küçükakyüz, Tavşanoğlu, \& Akbaş 2015; Tavşanoğlu et al. 2017).

To test whether the germination and seedling growth of species with physically-dormant seeds responded to smoke and smoke-related compounds, a heat-shock treatment was conducted to break physical seed dormancy in species of Cistaceae and Malvaceae (well-known families with physical dormancy). To do this, seeds were placed in aluminum pockets and exposed to heat at $100^{\circ} \mathrm{C}$ for $5 \mathrm{~min}$ in an electric oven, a heat shock temperature that was previously proved to stimulate germination in many hard-seeded families, including Cistaceae and Malvaceae (Thanos et al. 1992; Moreira et al. 2010; and preliminary tests with our species). All treatments performed in this experiment consisted of 3 replicates of 25 seeds. Petri dishes were placed in an incubator in the dark at $20 \underline{\Psi}{ }^{\circ} \mathrm{C}$, suitable conditions for the germination of many Mediterranean plants (Luna, Pérez, Torres, \& Moreno 2012; Çatav et al. 2015). The seeds were monitored for germination once a week until the end of the experiment (35 days). Germinated seeds were counted and removed from Petri dishes at every check. Visible radicle protrusion was the criterion of germination. The viability of non-germinated seeds was checked by the cut test at the end of the experiment, and seeds with an intact embryo were considered viable.

\section{The seedling growth experiment}

The seedling growth experiment was performed in a subset of 16 species and conducted under the same preincubation conditions as the germination experiment. Each treatment consisted of three Petri dishes with five seedlings, which were placed in a plant growth chamber at $20_{-} 2{ }^{\circ} \mathrm{C}$ and kept under white light $\left(100 \mathbf{M m o l ~ m} \mathrm{m}^{-2} \mathrm{~s}^{-1}\right)$ in $16 \mathrm{~h} / 8 \mathrm{~h}$ (light/darkness) photoperiod conditions. The experiment was terminated after two or three weeks, depending on the germination rate of the species. At the end of this period, we measured the primary shoot and root length of the seedlings from digital photographs by using ImageJ software (https://imagej.nih.gov/ij/). The total seedling length and root-shoot length ratio were then calculated. Finally, the seedling dry weight of each species was determined after placing the seedlings in an electric oven at $70^{\circ} \mathrm{C}$ for $24 \mathrm{~h}$.

\section{Data analysis}

Before statistical analysis of the germination data, empty seeds were excluded from the data set. For each replicate, treatment and species combination, seeds were categorized as germinated or non-germinated, before the final germination of each treatment and species was compared with the control using analysis of deviance (generalized linear model, GLM) assuming a binomial error distribution (Moreira et al. 2010; Çatav et al. 2015). In this analysis, the Petri dish was the replicate unit with their corresponding number of germinated and non-germinated seeds. We performed additional GLM analyses to determine whether germination of the $\mathrm{KAR}_{1}$ and MAN combination was significantly higher than $\mathrm{KAR}_{1}$ and MAN treatments alone. These analyses were made only for species whose germination was statistically higher in the $\mathrm{KAR}_{1}+$ MAN combined treatment than the control. Thus, we were able to determine whether the combination of $\mathrm{KAR}_{1}$ and MAN has a synergetic effect on the germination of these species (i.e. significantly higher germination than for either of the two separately). Finally, a pairwise correlation matrix (Pearson's r) among all treatments was computed from the changes in germination percentage relative to control, considering the 33 species.

The role of growth form in the stimulation of germination by various treatments was explored using a general linear mixed model (LMM) with growth form as the fixed factor and genus within family as the random factor. Growth form was classified as 'annual', 'perennial' (including variable herbs and geophytes) and 'woody'. The magnitude of germination (i.e. increase or decrease in germination relative to the control) for each species and treatment combination was estimated from mean germination values in each treatment and the control before inclusion in the model as a dependent 
Table 2. Species in which germination (G) and at least one seedling growth parameter (S) are enhanced by smoke water, smoke-derived compounds, $\mathrm{KNO}_{3}$ and/or $\mathrm{GA}_{3}$. For species codes and growth forms (GF), see Table 1. Group gives information about the group of species in which germination and/or seedling growth experiments were conducted ( $\mathrm{I}$ = both germination and seedling growth experiments; II = only germination experiment; and III = only seedling growth experiment). SW, $\mathrm{KAR}_{1}$ and MAN are abbreviations for smoke water, karrikinolide and mandelonitrile, respectively.

\begin{tabular}{|c|c|c|c|c|c|c|c|c|}
\hline \multirow[t]{2}{*}{ Group } & \multirow[t]{2}{*}{ Species } & \multirow[t]{2}{*}{ GF } & \multicolumn{6}{|c|}{ Treatment } \\
\hline & & & SW & $\mathrm{KAR}_{1}$ & MAN & $\mathrm{KAR}_{1}+\mathrm{MAN}$ & $\mathrm{KNO}_{3}$ & $\mathrm{GA}_{3}$ \\
\hline \multirow[t]{12}{*}{ I } & PEX & a & G & G & G & $G-S$ & $G-S$ & - \\
\hline & RTU & $\mathrm{p}$ & G & G & G & G & G & - \\
\hline & SMI & $\mathrm{p}$ & - & $\mathrm{S}$ & - & $G-S$ & $\mathrm{~S}$ & $\mathrm{~S}$ \\
\hline & TLE & p & S & $\mathrm{S}$ & $\mathrm{S}$ & $\mathrm{S}$ & $\mathrm{S}$ & - \\
\hline & DCA & $\mathrm{v}$ & - & - & $\mathrm{S}$ & $\mathrm{S}$ & G & $\mathrm{S}$ \\
\hline & $\mathrm{CFO}$ & $\mathrm{v}$ & $\mathrm{s}$ & - & - & - & $\mathrm{S}$ & $\mathrm{S}$ \\
\hline & ABA & a & - & - & - & G & G & - \\
\hline & ITI & $\mathrm{p}$ & G & - & - & - & G & - \\
\hline & CCR & w & - & - & $\mathrm{S}$ & - & - & $\mathrm{S}$ \\
\hline & TSP & $\mathrm{p}$ & - & $\mathrm{s}$ & - & - & $\mathrm{S}$ & - \\
\hline & SVU & $\mathrm{p}$ & - & - & - & - & $\mathrm{S}$ & - \\
\hline & PSP & $\mathrm{v}$ & - & - & - & S & - & - \\
\hline \multirow[t]{9}{*}{ II } & APA & $\mathrm{p}$ & G & - & G & G & G & G \\
\hline & AFU & a & G & - & - & G & G & G \\
\hline & OCA & $\mathrm{v}$ & G & G & - & G & G & - \\
\hline & CBU & a & - & - & - & G & G & - \\
\hline & SBE & a & - & - & G & G & - & - \\
\hline & SCR & $\mathrm{p}$ & - & G & - & G & - & - \\
\hline & HSA & a & G & - & - & - & - & - \\
\hline & CSA & $\mathrm{w}$ & - & - & - & - & - & G \\
\hline & TSPI & $\mathrm{w}$ & - & - & - & G & - & - \\
\hline III & TLO & $\mathrm{v}$ & $\mathrm{S}$ & - & - & $\mathrm{S}$ & $\mathrm{S}$ & - \\
\hline Total & & & $7 G-3 S$ & $4 G-3 S$ & $4 G-3 S$ & $11 G-6 S$ & $9 G-7 S$ & $3 G-4 S$ \\
\hline
\end{tabular}

variable. All data were arcsine transformed prior to analysis for improving normality. In the analysis, we tested the differences between the model with fixed (i.e. growth form) and random factors (i.e. genus within family) and the model with only the random factor (i.e. the null model) using a likelihood ratio test. The hypotheses tested in the analyses were different for each variable and treatment combination so the critical significance level for the analysis was considered as $a=0.05$.

Seedling growth parameters were analyzed by one-way analysis of variance (ANOVA) followed by Dunnett's test to compare the difference of each treatment with the control. Assumptions of data normality and homogeneity of variance were tested using the Shapiro-Wilk and Bartlett's tests respectively before the analysis. When needed, seedling growth data were log-transformed to meet normality and homoscedasticity assumptions.

For all analyses (except for the LMM analysis on the effect of growth form), the significance level was set at $p<0.01$ due to the large number of pairwise comparisons (Moreira et al. 2010). LMMs were conducted using nlme package (Pinheiro, Bates, DebRoy, \& Sarkar 2014), implemented in R version 3.1.

\section{Results}

\section{Germination}

We found substantial variability in dormancy levels among the studied species. Ten species showed high-degree dormancy with $<10 \%$ germination in control whereas eight species had very low dormancy with $>90 \%$ germination (see Supplementary Appendix A: Table 1). Germination percentages in straw- and cellulose-derived smoke water solutions were highly correlated $(\mathrm{r}=0.82 ; p<0.001)$. These solutions also significantly increased the proportion of germinated seeds in six and three species, respectively. While both KAR 1 and MAN treatments separately triggered germination of four species, the combination of these two compounds stimulated germination in eleven species. Phleum exaratum and Rumex tuberosus were stimulated by both $\mathrm{KAR}_{1}$ and MAN treatments. However, germination responses to $\mathrm{KAR}_{1}$ and MAN were not significantly correlated $(\mathrm{r}=0.29 ; p=0.100)$. For example, germination of Silene behen and Alcea pallida was enhanced by MAN, but not $\mathrm{KAR}_{1}$ while germination of Onopordum caricum and Stachys cretica was enhanced by KAR 1 but not MAN (Table 2; see Supplementary Appendix A: 


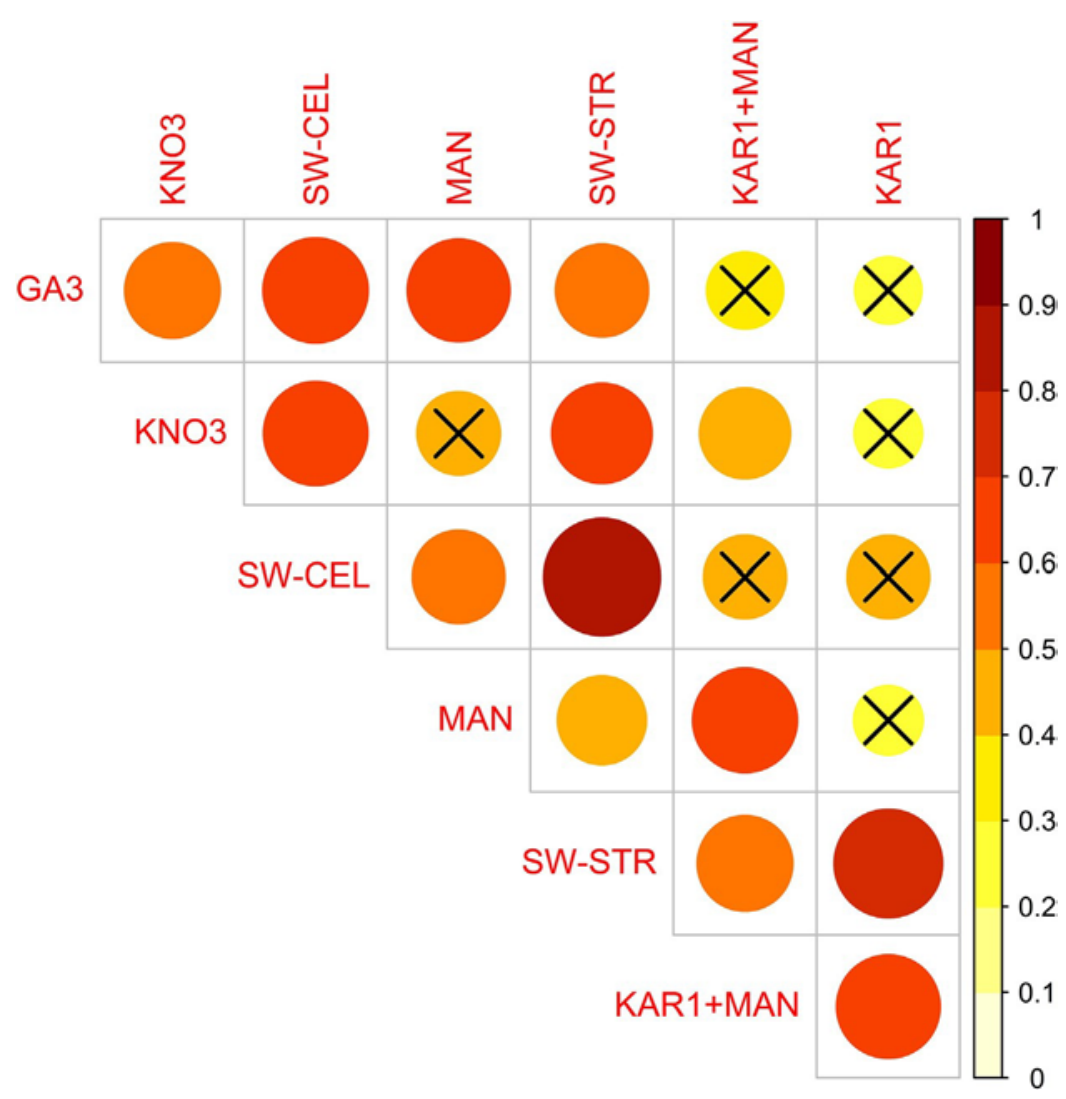

Fig. 1. Correlation matrix of the changes in germination percentage relative to control in 33 species for the tested treatments. The magnitude of correlation coefficients is represented simultaneously by the heat map colors and the size of the circles. Crosses indicate non-significant correlations $(p>0.01)$ between treatments. SW-STR, SW-CEL, KAR 1 and MAN are abbreviations for straw-derived smoke water, cellulosederived smoke water, karrikinolide and mandelonitrile, respectively.

Table 1). The $\mathrm{KAR}_{1}+\mathrm{MAN}$ combination and $\mathrm{KNO}_{3}$ were the most effective treatments, promoting germination of eleven and nine species, respectively (Table 2; see Supplementary Appendix A: Table 1). Of the 33 species examined, germination of three was promoted by $\mathrm{GA}_{3}$. On the other hand, $\mathrm{GA}_{3}$ and MAN treatments reduced germination compared to the control in two and one species, respectively (see Supplementary Appendix A: Table 1). Finally, the comparison of the individual $\mathrm{KAR}_{1}$ and MAN treatments with the combination of these two (KAR 1 + MAN combined treatment) showed that both compounds had a synergistic effect on germination in three species (see Supplementary Appendix A: Table 1).

The magnitude of germination in the straw-derived smoke water treatment was positively correlated with that of all other treatments, notably with cellulose-derived smoke water $(\mathrm{r}=0.82, p<0.001)$ and $\mathrm{KAR}_{1}(\mathrm{r}=0.71, p<0.001)$ treatments (Fig. 1). GA3 also showed positive correlations with straw-derived smoke water $(\mathrm{r}=0.52 ; p=0.002)$, cellulosederived smoke water ( $\mathrm{r}=0.66 ; p<0.001)$, MAN $(\mathrm{r}=0.63$; $p<0.001)$ and $\mathrm{KNO}_{3}(\mathrm{r}=0.55 ; p=0.001)$, but not with $\mathrm{KAR}_{1}$ $(\mathrm{r}=0.27 ; p=0.125)$. $\mathrm{KAR}_{1}$ was not correlated with any treatments except straw-derived smoke water and the combination of $\mathrm{KAR}_{1}+$ MAN (Fig. 1).
Grouping species by growth form showed that annual plants had a higher level of germination stimulation than perennial plants in MAN, $\mathrm{KAR}_{1}+\mathrm{MAN}$ and $\mathrm{KNO}_{3}$ treatments in comparison to the control. However, the effect was only statistically significant in the $\mathrm{KAR}_{1}+$ MAN treatment $(p<0.05$; Fig. 2).

\section{The seedling growth experiment}

All treatments except for straw-derived smoke water significantly increased root length in at least two species (see Supplementary Appendix A: Table 2). The $\mathrm{KAR}_{1}+$ MAN combination and $\mathrm{KNO}_{3}$ were the most effective treatments for increasing root length. Both treatments significantly increased root length compared to the control in four species. The shoot length of Crepis foetida and Sanguisorba minor significantly increased after $\mathrm{GA}_{3}$ treatment whereas the other treatments did not affect shoot length in any of the species (see Supplementary Appendix A: Table 3). Cellulose-derived smoke water, KAR 1 and MAN increased total seedling length in Tragopogon longirostis, S. minor, and Daucus carota, respectively (see Supplementary Appendix A: Table 4). The total seedling length of these three species was also enhanced by the combination of $\mathrm{KAR}_{1}$ and MAN com- 


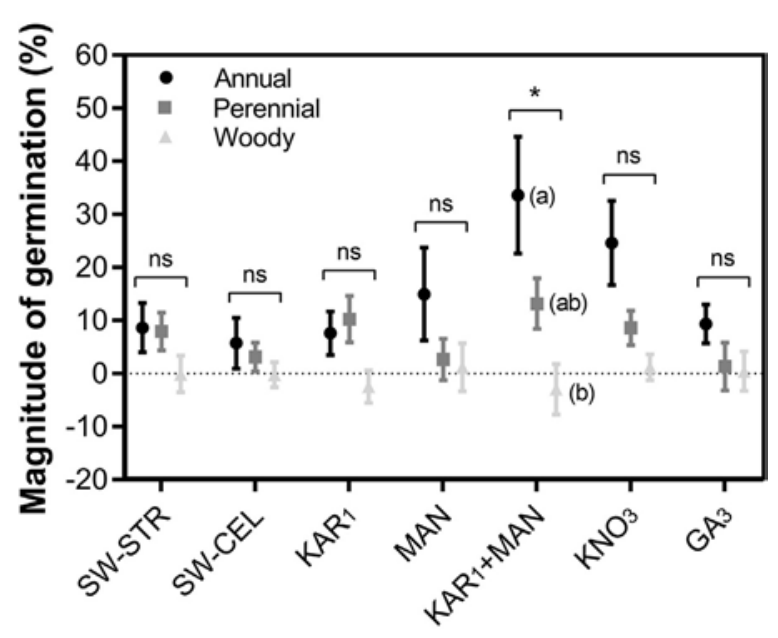

Treatment

Fig. 2. The role of growth form in the stimulation of germination. Values given are mean ${ }_{-} \mathrm{SE}$ of the magnitude of germination $(\%)$. '*' and 'ns' represent statistical significance $(p<0.05)$ and non-significance $(p>0.05)$ associated with the linear mixed model (LMM), respectively. Bars marked by different letters within the same treatment group are significantly different $(p<0.05)$. For abbreviations, see Fig. 1.

pared to control. $\mathrm{KNO}_{3}$ and $\mathrm{GA}_{3}$ treatments increased total seedling length of a quarter of the study species (see Supplementary Appendix A: Table 4). The root-shoot ratios of at least two species were increased by all treatments except straw-derived smoke water and GA3 (see Supplementary Appendix A: Table 5). Among the treatments that increased the root-shoot ratio, $\mathrm{KAR}_{1}+\mathrm{MAN}$ and $\mathrm{KNO}_{3}$ were the most efficient as they increased the ratio of four and three species respectively. Cellulose-derived smoke water,
$\mathrm{KNO}_{3}$ and $\mathrm{GA}_{3}$ treatments significantly increased seedling dry weight in $C$. foetida (see Supplementary Appendix A: Table 6). Moreover, seedling dry weight in P. exaratum was enhanced by $\mathrm{KAR}_{1}+\mathrm{MAN}$ and $\mathrm{KNO}_{3}$ treatments. Finally, cellulose-derived smoke water and $\mathrm{KAR}_{1}+\mathrm{MAN}$ treatments both increased seedling dry weight in T. longirostis. Overall, $\mathrm{KNO}_{3}$ and the combination of $\mathrm{KAR}_{1}+$ MAN affected at least one seedling growth variable in seven and six species respectively (Table 2). However, the seedling growth parameters of six species were unaffected by any treatment.

\section{Discussion}

Our results show that the germination of seven species and the seedling growth of three species in our study are enhanced by smoke (i.e. by any of the two smoke water treatments; SW in Table 2). All smoke-stimulated species were herbs (annual or perennial) from six different families, while none of the woody species responded positively to smoke. Although the overall effect (considering all species) was not significant (Fig. 2), smoke was important for some species. This is in agreement with previous research in the Mediterranean Basin (Moreira et al. 2010; Tormo, Moreira, \& Pausas 2014) and elsewhere; in all Mediterranean-type ecosystems, smoke-stimulated germination is only relevant to a small subset of species (Keeley \& Fotheringham 1998; Tieu, Dixon, Meney, \& Sivasithamparam 2001; Brown, Van Staden, Daws, \& Johnson 2003; Gómez-González, Sierra-Almeida, \& Cavieres 2008). Different species have different strategies for persisting in fire-prone ecosystems, with smoke-stimulation of germination being just one of them (Keeley et al. 2011, 2012).

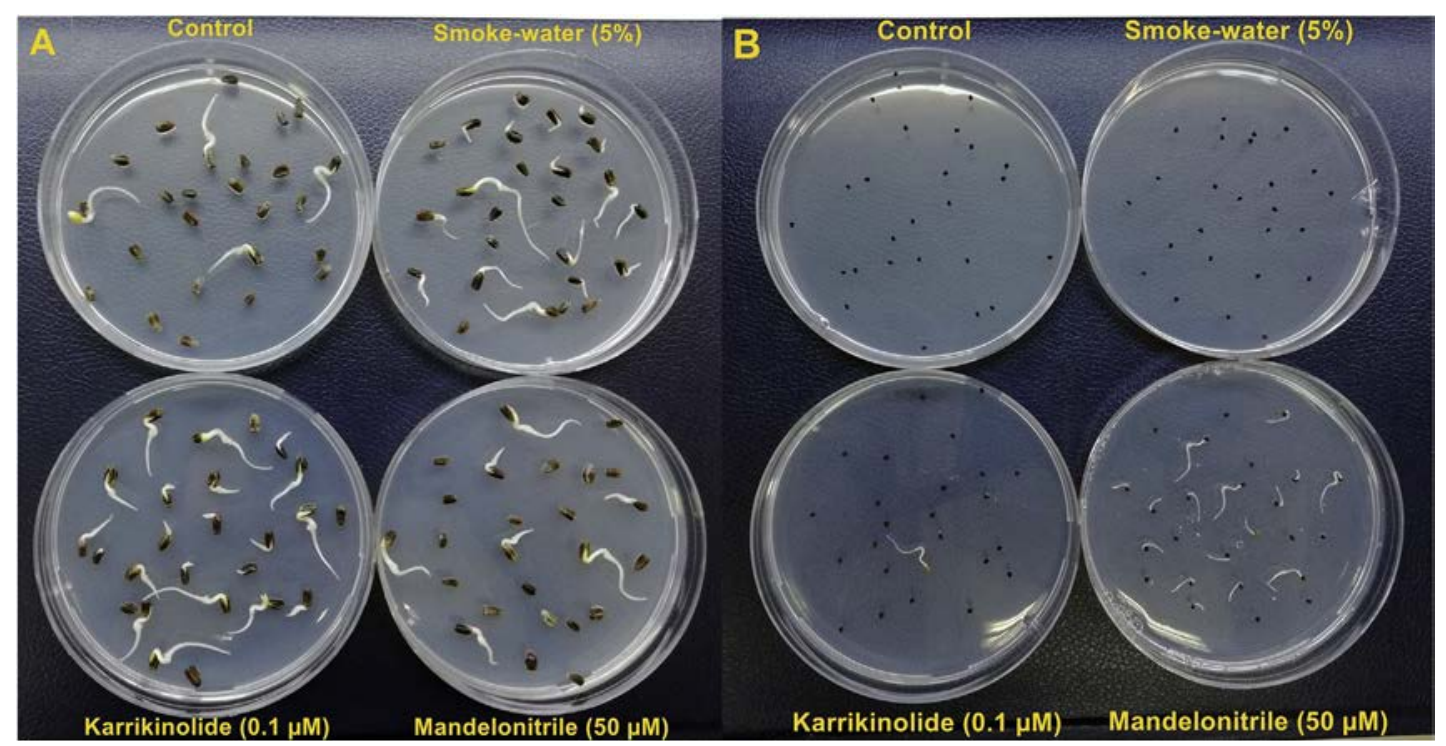

Fig. 3. Germination response of Onopordum caricum (A) and Silene behen (B) to smoke and smoke-derived chemicals. Photographs were taken after 7 days of incubation period. 
Although the stimulatory effect of smoke chemicals (KAR 1 and cyanohydrin) on germination has been well documented for many species in South Africa and Australia (Dixon et al. 2009; Flematti et al. 2011; Downes, Light, Pošta, Kohout, \& Van Staden 2014), only one species was previously documented for the Mediterranean Basin (C. rubrifolium, Tavşanoğlu et al., 2017). Our study is thus the first comprehensive attempt to explore the effects of specific chemicals found in smoke on Mediterranean plants. We present evidence on $\mathrm{KAR}_{1}$ and cyanohydrin-stimulated germination for several species, and conclude that the germination response to smoke-derived compounds in plants from the Mediterranean Basin is similar to those from other distant Mediterranean-type ecosystems. This result opens the possibility of using smoke and smoke-derived compounds in nurseries and restoration projects with wild plants as it is currently being tested in other Mediterranean-type ecosystems (e.g., Rokich \& Dixon 2007; Erickson, Shackelford, Dixon, Turner, \& Merritt 2016).

In this study, germination from smoke-isolated compounds was significantly correlated with smoke germination (Fig. 1), although the variability in germination among compounds and between compounds and smoke was important (Table 2; see Supplementary Appendix A: Table 1). That is, some species were stimulated by one compound but not others, suggesting different sensitivities in different species (Fig. 3). For instance, some species that were stimulated by smoke were not stimulated by $\mathrm{KAR}_{1}$, emphasizing that $\mathrm{KAR}_{1}$ is not a universal factor in smokestimulated germination (Keeley \& Pausas 2018). In fact, the occurrence of smoke-stimulated germination in different plant families and by different compounds suggests that this trait has evolved in different times and places by convergent evolution (Keeley \& Pausas 2018). While $\mathrm{KNO}_{3}$ stimulated germination in most species (Table 2; see Supplementary Appendix A: Table 1), the combination of $\mathrm{KAR}_{1}$ and MAN was the most effective treatment for stimulating germination; even considering the average of all species, the effect was significant (Fig. 2). The effect of these two compounds together was stronger than the effect of smoke, and stronger than the effect of either compound alone. These results suggest that (1) they are powerful chemicals for breaking seed dormancy; (2) there is a synergistic effect between them (as observed in some annual plants particularly; see Supplementary Appendix A: Table 1; Tavşanoğlu et al. 2017); and (3) smoke contains inhibitors (e.g. 3,4,5-trimethylfuran-2(5H)-one, and 5,5-dimethylfuran-2(5H)-one) that limit potential germination (Light, Burger, Staerk, Kohout, \& Van Staden 2010; Burger et al. 2018). The presence of stimulatory, inhibitory and synergistic effects of smoke chemicals on germination, together with the high variability in their concentration on arriving to the seeds in the soil seed bank, makes it difficult to balance the positive and negative effects in field conditions.
Even though annual herbaceous species are an important component of post-fire plant communities in northernhemisphere Mediterranean-type ecosystems (Kazanis \& Arianoutsou 2004; Keeley, Fotheringham, \& Baer-Keeley 2005; Keeley et al. 2012), there is limited information on the fire-related germination of annual plants in the Mediterranean Basin, as only $12 \%$ of species tested for germination with fire cues are annual (or biennial) species in this region (Moreira \& Pausas 2018). Of the seven annual species examined in our study, six showed significantly increased germination compared to the control in at least one of the fire-related cues tested (see Supplementary Appendix A: Table 1). Furthermore, annual plants had a higher level of germination stimulation than perennial plants in some of the smoke chemical treatments (Fig. 2). These findings are consistent with those of studies conducted in other Mediterranean-type ecosystems (Keeley \& Bond 1997; Keeley \& Fotheringham 1998), and a study indicating the germination of annuals is more prone to smoke stimulation than other growth forms (Abedi, Zaki, Erfanzadeh, \& Naqinezhad 2018). Thus, this result makes a significant contribution to filling the gap in the literature for the Mediterranean Basin.

The mode of action of $\mathrm{KAR}_{1}$ in stimulating seed germination has gained attention in recent years. Some studies suggest that $\mathrm{KAR}_{1}$ can act in a similar fashion to $\mathrm{GA}_{3}$ (Merritt et al. 2006; Daws et al. 2007; Stevens, Merritt, Flematti, Ghisalberti, \& Dixon 2007; Cembrowska-Lech et al. 2015). However, other studies have found no relationship in the germination response between $\mathrm{KAR}_{1}$ and $\mathrm{GA}_{3}$ (Commander, Merritt, Rokich, Flematti, \& Dixon 2008; Tavşanoğlu et al. 2017). Our results supported the latter (Fig. 1, see Supplementary Appendix A: Table 1). These contrasting findings indicate that further detailed experiments are needed involving a wider range of concentrations of $\mathrm{KAR}_{1}$ and $\mathrm{GA}_{3}$, and including more species for a better understanding of the similarities and differences in germination response across species and compounds.

Our results on seedling growth indicate that smoke and smoke chemicals are more effective in stimulating root growth than shoot growth (see Supplementary Appendix A: Table 5), as previously suggested by Moreira et al. (2010). The root lengths of five species were increased by at least one of the smoke-related treatments while none of the firerelated treatments significantly affected the shoot length of the studied species (see Supplementary Appendix A: Tables 2 and 3). A recent study (Wang et al. 2017) has demonstrated that smoke affects primary root growth and root hair elongation through reactive oxygen species-mediated redox signalling in Nicotiana attenuata, a post-fire annual. Moreover, they reported that, in this species, the main active constituent in smoke-induced root growth was catechol not karrikins. Therefore, the findings of our study and previous reports (Van Staden et al. 2006; Kulkarni, Sparg, \& Van Staden 2007; Wang et al. 2017) suggest that several smoke chemicals (e.g. $\mathrm{KAR}_{1}$, catechol and cyanohydrin) 
may play a role the stimulation of root growth. We recommend a comparative study to determine the relative roles of various smoke chemicals in the stimulation of plant root growth. In such studies, moreover, simultaneous applications of smoke-derived compounds may provide valuable insights into the interactive effects of these chemicals on seedling growth.

\section{Funding}

This study was financially supported by the Scientific Research Projects Coordination Unit of Muğla Sitkı Koçman University (grant number 15/153).

\section{Acknowledgements}

We are grateful to Kenan Akbas, for the identification of the studied plant species. The seeds were collected in the field with the permission of the Ministry of Food, Agriculture and Livestock of the Republic of Turkey (no: 10032, date: 27.12.2013). This study was a part of the PhD thesis of the first author. This is a contribution to the project PROMETEO/2016/021 (Generalitat Valenciana, Spain).

\section{Appendix A. Supplementary data}

Supplementary data associated with this article can be found, in the online version, at https://doi.org/10.1016/j.baae.2018.05.005.

\section{References}

Abedi, M., Zaki, E., Erfanzadeh, R., \& Naqinezhad, A. (2018). Germination patterns of the scrublands in response to smoke: The role of functional groups and the effect of smoke treatment method. South African Journal of Botany, 115, 231-236.

Adkins, S. W., \& Peters, N. C. B. (2001). Smoke derived from burnt vegetation stimulates germination of arable weeds. Seed Science Research, 11, 213-222.

Baldos, O. C., DeFrank, J., \& Sakamoto, G. S. (2015). Germination response of dormant tanglehead (Heteropogon contortus) seeds to smoke-infused water and the smoke-associated stimulatory compounds karrikinolide and cyanide. HortScience, 50, 421-429.

Baskin, C. C., \& Baskin, J. M. (2014). Seeds: Ecology, biogeography, and, evolution of dormancy and germination (2nd ed.). Oxford: Elsevier.

Bond, W. J., \& Keeley, J. E. (2005). Fire as a global 'herbivore': The ecology and evolution of flammable ecosystems. Trends in Ecology \& Evolution, 20, 387-394.

Brown, N. A. C., \& Van Staden, J. (1997). Smoke as a germination cue: A review. Plant Growth Regulation, 22,115-124.
Brown, N. A. C., Van Staden, J., Daws, M. I., \& Johnson, T. (2003). Patterns in the seed germination response to smoke in plants from the Cape Floristic Region. South African Journal of Botany, 69, 514-525.

Burger, B. V., Pos`ta, M., Light, M. E., Kulkarni, M. G., Viviers, M. Z., \& Van Staden, J. (2018). More butenolides from plant-derived smoke with germination inhibitory activity against karrikinolide. South African Journal of Botany, 115, 256-263.

Çatav, Ş. S., Küçükakyüz, K., Tavşanoğlu, Ç., \& Akbaş, K. (2015). Effects of aqueous smoke and nitrate treatments on germination of 12 eastern Mediterranean Basin plants. Annales Botanici Fennici, 52, 93-100.

Cembrowska-Lech, D., Koprowski, M., \& Kępczyński, J. (2015). Germination induction of dormant Avena fatua caryopses by $\mathrm{KAR}_{1}$ and $\mathrm{GA}_{3}$ involving the control of reactive oxygen species $\left(\mathrm{H}_{2} \mathrm{O}_{2}\right.$ and $\left.\mathrm{O}_{2}{ }^{-}\right)$and enzymatic antioxidants (superoxide dismutase and catalase) both in the embryo and the aleurone layers. Journal of Plant Physiology, 176, 169-179.

Cembrowska-Lech, D., \& Kępczyński, J. (2016). Gibberellin-like effects of $\mathrm{KAR}_{1}$ on dormancy release of Avena fatua caryopses include participation of non-enzymatic antioxidants and cell cycle activation in embryos. Planta, 243, 531-548.

Chiwocha, S. D., Dixon, K. W., Flematti, G. R., Ghisalberti, E. L., Merritt, D. J., Nelson, D. C., et al. (2009). Karrikins: A new family of plant growth regulators in smoke. Plant Science, 177, 252-256.

Chuvieco, E., Giglio, L., \& Justice, C. (2008). Global characterization of fire activity: Toward defining fire regimes from Earth observation data. Global Change Biology, 14, 1488-1502.

Commander, L. E., Merritt, D. J., Rokich, D. P., Flematti, G. R., \& Dixon, K. W. (2008). Seed germination of Solanum spp. (Solanaceae) for use in rehabilitation and commercial industries. Australian Journal of Botany, 56, 333-341.

Davis, P. H. (1965-1985). Flora of Turkey and the East Aegean Islands (Vols. 1-9). Edinburgh: Edinburgh Univ. Press.

Daws, M. I., Davies, J., Pritchard, H. W., Brown, N. A. C., \& Van Staden, J. (2007). Butenolide from plant-derived smoke enhances germination and seedling growth of arable weed species. Plant Growth Regulation, 51, 73-82.

Dixon, K. W., Roche, S., \& Pate, J. S. (1995). The promotive effect of smoke derived from burnt native vegetation on seed germination of Western Australian plants. Oecologia, 101, 185-192.

Dixon, K. W., Merritt, D. J., Flematti, G. R., \& Ghisalberti, E. L. (2009). Karrikinolide - A phytoreactive compound derived from smoke with applications in horticulture, ecological restoration and agriculture. Acta Horticulturae, 813, 155-170.

Downes, K. S., Lamont, B. B., Light, M. E., \& Van Staden, J. (2010). The fire ephemeral Tersonia cyathiflora (Gyrostemonaceae) germinates in response to smoke but not the butenolide 3-methyl2H-furo[2,3-c]pyran-2-one. Annals of Botany, 106, 381-384.

Downes, K. S., Light, M. E., Pošta, M., Kohout, L., \& Van Staden, J. (2013). Comparison of germination responses of Anigozanthos flavidus (Haemodoraceae), Gyrostemon racemiger and Gyrostemon ramulosus (Gyrostemonaceae) to smoke-water and the smoke-derived compounds karrikinolide $\left(\mathrm{KAR}_{1}\right)$ and glyceronitrile. Annals of Botany, 111, 489-497.

Downes, K. S., Light, M. E., Pos`ta, M., Kohout, L., \& Van Staden, J. (2014). Do fire-related cues, including smoke-water, karrikinolide, glyceronitrile and nitrate, stimulatethe germination of 17 
Anigozanthos taxa and Blancoa canescens (Haemodoraceae)? Australian Journal of Botany, 62, 347-358.

Downes, K. S., Light, M. E., Pošta, M., \& Van Staden, J, (2015). Fire-related cues and the germination of eight Conostylis (Haemodoraceae) taxa, when freshly collected, after burial and after laboratory storage. Seed Science Research, 25, 286-298.

Erickson, T. E., Shackelford, N., Dixon, K. W., Turner, S. R., \& Merritt, D. J. (2016). Overcoming physiological dormancy in seeds of Triodia (Poaceae) to improve restoration in the arid zone. Restoration Ecology, 24, 64-76.

Flematti, G. R., Ghisalberti, E. L., Dixon, K. W., \& Trengove, R. D. (2004). A compound from smoke that promotes seed germination. Science, 305, 977.

Flematti, G. R., Goddard-Borger, E. D., Merritt, D. J., Ghisalberti, E. L., Dixon, K. W., \& Trengove, R. D. (2007). Preparation of $2 \mathrm{H}$-furo[2,3-c]pyran-2-one derivatives and evaluation of their germination-promoting activity. Journal of Agriculture and Food Chemistry, 55, 2189-2194.

Flematti, G. R., Merritt, D. J., Piggott, M. J., Trengove, R. D., Smith, S. M., Dixon, K. W., et al. (2011). Burning vegetation produces cyanohydrins that liberate cyanide and stimulate seed germination. Nature Communications, 2, 360.

Glasspool, I. J., Edwards, D., \& Axe, L. (2004). Charcoal in the Silurian as evidence for the earliest wildfire. Geology, 32, 381-383.

Gómez-González, S., Sierra-Almeida, A., \& Cavieres, L. A. (2008). Does plant-derived smoke affect seed germination in dominant woody species of the Mediterranean matorral of central Chile? Forest Ecology and Management, 255, 1510-1515.

Hanley, M. E., \& Fenner, M. (1998). Pre-germination temperature and the survivorship and onward growth of Mediterranean firefollowing plant species. Acta Oecologica, 19, 181-187.

Herranz, J. M., Ferrandis, P., \& Martínez-Sánchez, J. J. (1998). Influence of heat on seed germination of seven Mediterranean Leguminosae species. Plant Ecology, 136, 95-103.

Jain, N., \& Van Staden, J. (2006). A smoke-derived butenolide improves early growth of tomato seedlings. Plant Growth Regulation, 50, 139-148.

Kazanis, D., \& Arianoutsou, M. (2004). Long-term post-fire vegetation dynamics in Pinus halepensis forests of Central Greece: A functional group approach. Plant Ecology, 171, 101-121.

Keeley, J. E., \& Bond, W. J. (1997). Convergent seed germination in South African fynbos and Californian chaparral. Plant Ecology, 133, 153-167.

Keeley, J. E., \& Fotheringham, C. J. (1998). Smoke-induced seed germination in California chaparral. Ecology, 79, 23202336.

Keeley, J. E., Fotheringham, C. J., \& Baer-Keeley, M. (2005). Factors affecting plant diversity during post-fire recovery and succession of Mediterranean-climate shrublands in California, USA. Diversity and Distributions, 11, 525-537.

Keeley, J. E., Pausas, J. G., Rundel, P. W., Bond, W. J., \& Bradstock, R. A. (2011). Fire as an evolutionary pressure shaping plant traits. Trends in Plant Science, 16, 406-411.

Keeley, J. E., Bond, W. J., Bradstock, R. A., Pausas, J. G., \& Rundel, P. W. (2012). Fire in Mediterranean ecosystems: Ecology, evolution and management. Cambridge: Cambridge University Press.

Keeley, J. E., \& Pausas, J. G. (2018). Evolution of ‘smoke’ induced seed germination in pyroendemic plants. South African Journal of Botany, 115, 251-255.
Kulkarni, M. G., Sparg, S. G., Light, M. E., \& Van Staden, J. (2006). Stimulation of rice (Oryza sativa L.) seedling vigour by smokewater and butenolide. Journal of Agronomy and Crop Science, 192, 395-398.

Kulkarni, M. G., Sparg, S. G., \& Van Staden, J. (2007). Germination and post-germination response of Acacia seeds to smoke-water and butenolide, a smoke-derived compound. Journal of Arid Environments, 69,177-187.

Lamont, B. B., \& Downes, K. S. (2011). Fire-stimulated flowering among resprouters and geophytes in Australia and South Africa. Plant Ecology, 212, 2111-2125.

Light, M. E., Daws, M. I., \& Van Staden, J. (2009). Smoke-derived butenolide: Towards understanding its biological effects. South African Journal of Botany, 75, 1-7.

Light, M. E., Burger, B. V., Staerk, D., Kohout, L., \& Van Staden, J. (2010). Butenolides from plant-derived smoke: Natural plantgrowth regulators with antagonistic actions on seed germination. Journal of Natural Products, 73(2), 267-269.

Luna, B., Pérez, B., Torres, I., \& Moreno, J. M. (2012). Effects of incubation temperature on seed germination of Mediterranean plants with different geographical distribution ranges. Folia Geobotanica, 47, 17-27.

Merritt, D. J., Kristiansen, M., Flematti, G. R., Turner, S. R., Ghisalberti, E. L., Trengove, R. D., et al. (2006). Effects of a butenolide present in smoke on light-mediated germination of Australian Asteraceae. Seed Science Research, 16, 29-35.

Merritt, D. J., Turner, S. R., Clarke, S., \& Dixon, K. W. (2007). Seed dormancy and germination stimulation syndromes for Australian temperate species. Australian Journal of Botany, 55, 336-344.

Moreira, B., Tormo, J., Estrelles, E., \& Pausas, J. G. (2010). Disentangling the role of heat and smoke as germination cues in Mediterranean Basin flora. Annals of Botany, 105, 627-635.

Moreira, B., \& Pausas, J. G. (2018). Shedding light through the smoke on the germination of Mediterranean Basin flora. South African Journal of Botany, 115, 244-250.

Nelson, D. C., Flematti, G. R., Ghisalberti, E. L., Dixon, K. W., \& Smith, S. M. (2012). Regulation of seed germination and seedling growth by chemical signals from burning vegetation. Annual Review of Plant Biology, 63, 107-130.

Paula, S., Arianoutsou, M., Kazanis, D., Tavsanoglu, C., Lloret, F., Buhk, C., et al. (2009). Fire-related traits for plant species of the Mediterranean Basin. Ecology, 90, 1420.

Pausas, J. G., \& Keeley, J. E. (2009). A burning story: The role of fire in the history of life. BioScience, 59, 593-601.

Pausas, J. G., Alessio, G. A., Moreira, B., \& Corcobado, G. (2012). Fires enhance flammability in Ulex parviflorus. New Phytologist, 193, 18-23.

Pausas, J. G., \& Ribeiro, E. (2017). Fire and plant diversity at the global scale. Global Ecology and Biogeography, 26, 889-897.

Pierce, S. M., Esler, K., \& Cowling, R. M. (1995). Smoke-induced germination of succulents (Mesembryanthemaceae) from fireprone and fire-free habitats in South Africa. Oecologia, 102, 520-522.

Pinheiro, J., Bates, D., DebRoy, S., \& Sarkar, D. (2014). nlme: linear and nonlinear mixed effects models. $R$ package version 3.1-117. Available at https://cran.r-project.org/package=nlme.

Rokich, D. P., \& Dixon, K. W.(2007). Recent advances in restoration ecology, with a focus on the Banksia woodland and the smoke germination tool. Australian Journal of Botany, 55, 375-389.

Singh, S., Kulkarni, M. G., \& Van Staden, J. (2014). Biochemical changes associated with gibberellic acid-like activity of smoke- 
water, karrikinolide and vermicompost leachate during seedling development of Phaseolus vulgaris L. Seed Science Research, 24, 63-70.

Sparg, S. G., Kulkarni, M. G., Light, M. E., \& Van Staden, J. (2005). Improving seedling vigour of indigenous medicinal plants with smoke. Bioresource Technology, 96, 1323-1330.

$\begin{array}{ccccc}\text { Stevens, } & \text { P. F. } & \text { (2001). } & \text { Angiosperm } & \text { Phy- } \\ \text { logeny } & \text { Website. } & \text { (Version } & \text { 14), July } & 2017 .\end{array}$ http://www.mobot.org/mobot/research/apweb/welcome.html.

Stevens, J. C., Merritt, D. J., Flematti, G. R., Ghisalberti, E. L., \& Dixon, K. W. (2007). Seed germination of agricultural weeds is promoted by the butenolide 3-methyl-2H-furo[2,3-c]pyran-2one under laboratory and field conditions. Plant and Soil, 298, 113-124.

Tavşanoğlu, Ç., Ergan, G., Çatav, Ş. S., Zare, G., Küçükakyüz, K., \& Özüdoğru, B. (2017). Multiple fire-related cues stimulate germination in Chaenorhinum rubrifolium (Plantaginaceae), a rare annual in the Mediterranean Basin. Seed Science Research, 27, 26-38.

Thanos, C. A., Georghiou, K., Kadis, C., \& Pantazi, C. (1992). Cistaceae: A plant family with hard seeds. Israel Journal of Botany, $41,251-263$.
Tieu, A., Dixon, K. W., Meney, K. A., \& Sivasithamparam, K. (2001). The interaction of heat and smoke in the release of seed dormancy in seven species from southwestern Western Australia. Annals of Botany, 88, 259-265.

Tormo, J., Moreira, B., \& Pausas, J. G. (2014). Field evidence of smoke-stimulated seedling emergence and establishment in Mediterranean Basin flora. Journal of Vegetation Science, 25, 771-777.

Van Staden, J., Jäger, A. K., Light, M. E., Burger, B. V., Brown, N. A. C., \& Thomas, T. H. (2004). Isolation of the major germination cue from plant-derived smoke. South African Journal of Botany, 70, 654-659.

Van Staden, J., Sparg, S. G., Kulkarni, M. G., \& Light, M. E. (2006). Post-germination effects of the smoke-derived compound 3-methyl-2H-furo[2,3-c]pyran-2-one, and its potential as a preconditioning agent. Field Crops Research, 98, 98105.

Wang, M., Schoettner, M., Xu, S., Paetz, C., Wilde, J., Baldwin, I. T., et al. (2017). Catechol, a major component of smoke, influences primary root growth and root hair elongation through reactive oxygen species-mediated redox signaling. New Phytologist, 213, 1755-1770. 